\title{
Stimulation of Haptoglobin Synthesis by Interleukin-6 and Tumor Necrosis Factor, But Not by Interleukin-1, in Bovine Primary Cultured Hepatocytes
}

\author{
Noriko NAKAGAWA-TOSA, Masami MORIMATSU, Masami KAWASAKI, Hiroki NAKATSUJI ${ }^{1}$, Bunei SYUTO, \\ and Masayuki SAITO \\ Department of Biochemistry, Faculty of Veterinary Medicine, and ${ }^{1)}$ Department of Animal Science, Faculty of Agriculture, Hokkaido \\ University, Sapporo 060, Japan
}

(Received 11 October 1994/Accepted 5 December 1994)

\begin{abstract}
The hepatic synthesis of acute phase proteins in ruminants has been suggested to be regulated by some mechanisms different from those in other species such as rodents and human. To explore possible regulatory factors unique to ruminants, we examined effects of interleukin (IL)-6, IL-1 and tumor necrosis factor (TNF), on haptoglobin (Hp) synthesis using a primary culture system of bovine hepatocytes. After bovine primary cultured hepatocytes were incubated in the presence of various concentrations of the cytokines, the synthesis and mRNA level of haptoglobin and albumin were measured by labeling with $\left[{ }^{35} \mathrm{~S}\right]$-methionine and immunoprecipitation, and by Northern blot analysis, respectively. Hp synthesis was dose-dependently increased by recombinant human (rh) IL-6, and also by rhTNF- $\alpha$, but to a less extent, while it was not affected by rhIL- $1 \beta$. The stimulatory effect is mainly pretranslational, because mRNA level of $\mathrm{Hp}$ changed in parallel with protein synthesis. In contrast, albumin synthesis was suppressed by these three cytokines similarly. These results are inconsistent with the previously proposed view that TNF and IL-1 overlap in their pathways leading to the transcriptional activation of many acute phase protein genes. In conclusion, there is a species-specific unique signaling system, especially for TNF, in transcriptional activation of bovine Hp gene.- KEY wORDS: acute phase protein, bovine, cytokine, haptoglobin, primary cultured hepatocyte.
\end{abstract}

J. Vet. Med.Sci. 57(2): 219-223, 1995

Infection and tissue injury elicit a dramatic change in the plasma level of some specific proteins, so-called acute phase protein (APP). APPs are well preserved through phylogeny and believed to play important protective roles in host defense against tissue damage and infections. It is now accepted that hepatic synthesis and secretion of APP are regulated by diverse inflammatory mediators such as immune cytokines and glucocorticoids. Particularly, the principal roles of interleukin (IL)-6, IL-1 and tumor necrosis factor (TNF) seem well established on the basis of their stimulatory effect on APP synthesis in in vitro systems using primary cultured hepatocytes or hepatoma cell lines $[4,6,11]$. According to the difference in the response to these cytokines, APPs are classified into two types: type $1 \mathrm{APP}\left(\right.$ e.g., $\alpha_{1}$-acid glycoprotein, C-reactive protein, and serum amyloid A) are regulated by IL-1 and TNF, whereas type 2 APP (e.g., $\alpha_{2}$-macroglobulin and fibrinogen) by IL,-6 [4, 6]. In both types of APP, glucocorticoids enhance the effect of cytokines synergistically $[4,6,11]$.

Cross-species comparisons have indicated that there is a high degree of similarity among species in the qualitative and quantitative patterns of APP responses, and that species differences do not generally exist in the division of two APP types [4]. However, haptoglobin ( $\mathrm{Hp})$ is a unique APP so that it is classified as a type 1 APP in the rat while a type 2. APP in human [3, 6, 7]. Moreover, although in both the rat and human serum level of $\mathrm{Hp}$ increases only a few folds [11], in the bovine and goat it increases more than 100 -folds after inflammatory stimuli $[15,19,26]$. Thus these results suggest that synthesis of ruminant $\mathrm{Hp}$ seems to be regulated by some unique systems different from those in other species. In support of this idea, Higuchi et al. [12] recently demonstrated using a primary culture system of bovine hepatocytes that Hp synthesis is increased remarkably by glucocorticoids alone. Their results are apparently different from those in rodent and human hepatocytes, where the major action of glucocorticoids is to enhance the stimulatory effect of cytokines synergistically. However, as far as we know, there has been no report on the regulatory mechanisms of cytokines themselves in ruminant APP synthesis. In this study, we examined effects of IL-6, IL-1 and TNF on Hp synthesis in primary cultured bovine hepatocytes to explore possible regulatory mechanisms unique to this species.

MATERIALS AND METHODS

Animals and chemicals: Four healthy Holstein calves (1-8 weeks old) and one healthy Holstein cow (3 years old) were used in this study.

The following chemicals were purchased; Williams' medium E (WE), methionine-free Dulbecco's modified Eagle's medium (DME) (Gibco, Grand Island, NY, U.S.A.); fetal calf serum (FCS) (Flow Laboratories, McLean, VA, U.S.A.); streptomycin, penicillin (Meiji, Tokyo); fungizone (Bristol-Myers Squibb, Tokyo); phenylmethylsulfonyl fluoride (PMSF) (Nacalai Tesque, Kyoto); L- $\left[{ }^{35} \mathrm{~S}\right]$-methionine (>37.0 TBq/mmol) (DuPont, Boston, MA, U.S.A.); rabbit anti-bovine albumin antiserum (Daco Japan, Kyoto); protein A Sepharose FF (Pharmacia-LKB Biotechnology, Uppsala, Sweden); leupeptin, pepstatin (Peptide Institute, Osaka); pre- 
stained SDS-PAGE standards (Bio-Rad, Richmond, CA, U.S.A.); nick-translation kit, hybridization transfer membranes (Hybond N) (Amersham International, Buckinghamshire, England); $\alpha-\left[{ }^{32} \mathrm{P}\right]-\mathrm{dCTP}(>111 \mathrm{TBq} / \mathrm{mmol})$ (Hungarian Academy of Sciences, Budapest, Hungary). Recombinant human (rh) IL-1 $\beta$ (specific activity, $2 \times 10^{7}$ $\mathrm{U} / \mathrm{mg}$ protein) was kindly provided from Dr. Y. Hirai (Otsuka Pharmaceutical, Tokushima), rhIL-6 (specific activity, $5 \times 10^{6} \mathrm{U} / \mathrm{mg}$ protein) from Dr. K. Yasukawa (Tosoh, Ayase), and rhTNF- $\alpha$ (specific activity, $2.55 \times 10^{6}$ U/mg protein) from Dr. M. Kitaura (Dainippon Pharmaceutical, Osaka). Collagen was prepared from rat tail tendon according to the method of Elsdale and Bard [9]. Rabbit anti-bovine Hp antiserum was obtained as previously described [16].

Preparation of bovine hepatocyte monolayers: Suspensions of bovine hepatocytes were prepared as previously described [18]. Cell viability was usually $>90 \%$, as assessed by trypan blue exclusion test. Parenchymal cells were easily distinguishable, because they were several fold larger than nonparenchymal cells, and their purity was calculated to be $>95 \%$.

The cells were suspended in a culture medium to give a cell density of $5 \times 10^{5}$ cells $/ \mathrm{m} l$. The culture medium was WE supplemented with 5\% FCS, $1 \mu \mathrm{M}$ insulin, $10 \mu \mathrm{M}$ dexamethasone, $50 \mathrm{U} / \mathrm{m} l$ penicillin, $50 \mu \mathrm{g} / \mathrm{m} l$ streptomycin, $0.25 \mu \mathrm{g} / \mathrm{ml}$ fungizone, $1 \mathrm{mM} \mathrm{CaCl}$, and $1 \mathrm{mM} \mathrm{MgCl}_{2}$. Aliquots of $0.3 \mathrm{~m} l$ and $10 \mathrm{~m} l$ cell suspensions were seeded into $16 \mathrm{~mm}$ and $100 \mathrm{~mm}$ plastic tissue-culture dishes (Nunc, Roskilde, Denmark) coated with rat collagen and bovine fibronectin for the measurements of protein synthesis and mRNA levels, respectively. The dishes were incubated at $37^{\circ} \mathrm{C}$ in a humid atmosphere of $5 \% \mathrm{CO}_{2}$ in air for $3 \mathrm{hr}$, and then the medium was replaced by that lacking $\mathrm{CaCl}_{2}$ and $\mathrm{MgCl}_{2}$. After confluent monolayers were formed by overnight incubation, the monolayers were rinsed once by a medium lacking dexamethasone and cultured for further $24 \mathrm{hr}$ in the same medium, and used for following experiments of stimulation by cytokines.

Stimulation of hepatocytes: rhIL- 6 , rhIL- $1 \beta$ and rhTNF$\alpha$ were diluted in the culture medium immediately before use. Primary cultured hepatocytes were stimulated by various concentrations of rhIL- $1 \beta$, rhIL- 6 and rhTNF- $\alpha$ for $24 \mathrm{hr}$, and then used for the measurements of protein synthesis and mRNA level.

Labeling of hepatocytes and immunoprecipitation of $\mathrm{Hp}$ and albumin: Isotope labeling of hepatocytes and immunoprecipitation of $\mathrm{Hp}$ and albumin were accomplished according to the procedure of Andus et al. [1] with some modifications. Briefly, $\left[{ }^{35} \mathrm{~S}\right]$-methionine $(300 \mathrm{kBq})$ was added to $0.3 \mathrm{~m} l$ methionine-free DME culture medium. After incubation at $37^{\circ} \mathrm{C}$ for $2 \mathrm{hr}, 0.3 \mathrm{ml}$ culture supernatant was separated from the cells by centrifugation at $12,000 \times \mathrm{g}$ for $5 \mathrm{~min}$. The proteins in the medium were precipitated with $5 \%$ trichloroacetic acid (TCA) containing $30 \mathrm{mg}$ of carrier skim milk (Morinaga, Tokyo). The precipitate was washed three times with 5\% TCA, and solubilized in $1 \mathrm{~m} l$ of solution A $(0.1 \mathrm{M}$ Tris- $\mathrm{HCl}, \mathrm{pH} 7.6$,
$0.14 \mathrm{M} \mathrm{NaCl}, 5 \mathrm{mM}$ EDTA, $1 \%$ Triton X-100, $0.1 \%$ sodium dodecyl sulfate (SDS)) containing $1 \mathrm{mM}$ PMSF, 10 $\mu \mathrm{g} / \mathrm{m} l$ aprotinin, $10 \mu \mathrm{g} / \mathrm{m} l$ pepstatin, and $10 \mu \mathrm{g} / \mathrm{m} l$ leupeptin, and its radioactivity was counted in a liquid scintillation counter. The solubilized sample containing $2 \times 10^{4} \mathrm{cpm}$ in $1 \mathrm{~m} l$ was incubated with $5 \mu l$ of a specific antiserum against bovine $\mathrm{Hp}$ or albumin at $4^{\circ} \mathrm{C}$ overnight. The antigen-antibody complexes were bound to $7 \mathrm{mg}$ (dry mass) of protein A Sepharose FF, washed four times with solution $\mathrm{A}$ and twice with $50 \mathrm{mM}$ sodium phosphate buffer, $\mathrm{pH} 7.5$, and eluted by incubation with $20 \mu l$ of 0.1 $\mathrm{M}$ Tris- $\mathrm{HCl}, \mathrm{pH} 6.8,5 \%$ 2-mercaptoethanol, 5\% SDS and $10 \%$ glycerol at $95^{\circ} \mathrm{C}$ for $5 \mathrm{~min}$. The eluted protein samples were subjected to $12.5 \%$ SDS-polyacrylamide gel electrophoresis (PAGE) [13] and fluorography with BioImaging Analyzer BAS1000 (Fuji Photo Film, Tokyo).

Preparation of cDNAs: A bovine liver cDNA library was prepared in $\mathrm{pCDM} 8$ vector according to Seed and Aruffo [23]. A bovine Hp cDNA clone (1.3 kbp) was isolated by screening the library with a specific DNA probe prepared by polymerase chain reaction (Morimatsu et al., unpublished result). The cDNA clone was characterized by sequence determination and bacterial expression of their products followed by immunoblotting with specific antibodies and was used for preparing.

Isolation of RNA and Northern blot analysis: Total RNA was extracted from cells harvested from one dish by the method of Chomczynski and Sacchi [8] and glycogen contamination in the RNA pellet was diminished according to the procedure of Puissant and Houdebine [20]. Northern blot analysis was accomplished according to the standard protocols by Sambrook et al. [22]. Prior to transfer to nitrocellulose, total RNA, was denatured for $10 \mathrm{~min}$ at $65^{\circ} \mathrm{C}$ in $50 \%$ formamide, $2.2 \mathrm{M}$ formaldehyde, and $1 \times$ running buffer $(0.2 \mathrm{M}$ MOPS, $50 \mathrm{mM}$ sodium acetate, and $10 \mathrm{mM}$ EDTA, $\mathrm{pH}$ 7.0), and separated on a $1.5 \%$ agarose gel containing $2.2 \mathrm{M}$ formaldehyde and $1 \times$ running buffer. The membranes were prehybridized in $50 \%$ formamide, $0.1 \%$ SDS, $5 \times$ Denhardt's solution, $5 \times$ SSPE $\left(1 \times\right.$ SSPE is $0.15 \mathrm{M} \mathrm{NaCl}, 10 \mathrm{mM} \mathrm{NaH}_{2} \mathrm{PO}_{4}$, and 1 mM EDTA), and $100 \mu \mathrm{g} / \mathrm{m} l$ of denatured salmon sperm DNA for $5-6 \mathrm{hr}$ at $42^{\circ} \mathrm{C}$. The hybridization was carried out in the same buffer containing the bovine Hp cDNA probe $(1.0 \mathrm{kbp} P v u \mathrm{II}$ fragment labeled by nick-translation kit) at $42^{\circ} \mathrm{C}$ overnight. The membranes were washed in $2 \times$ SSC containing $0.1 \%$ SDS at $42^{\circ} \mathrm{C}$ for 30 min followed by $0.1 \times$ SSC containing $0.1 \%$ SDS at $65^{\circ} \mathrm{C}$ for $60 \mathrm{~min}$. The membranes were exposed to imaging plate for $2 \mathrm{hr}$ and analyzed with Bio-Imaging Analyzer BAS1000.

Data analysis: Values were expressed as means \pm SE. Statistical analyses were carried out by analysis of variance (ANOVA).

RESULTS

Primary cultured bovine hepatocytes were incubated with various concentrations of cytokines for $24 \mathrm{hr}$ and pulse-labeled with $\left[{ }^{35} \mathrm{~S}\right]$-methionine for $2 \mathrm{hr}$. Figure 1 


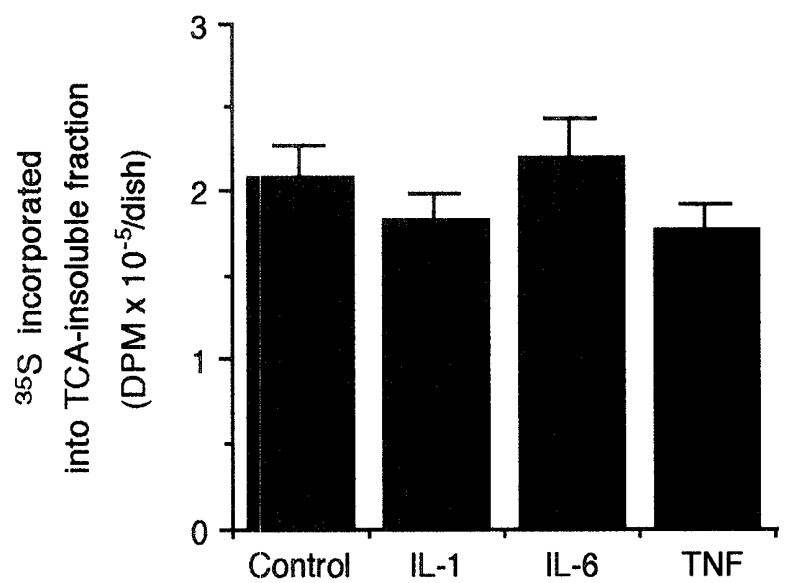

Fig. 1. Effects of rhIL-6, rhIL-1 $\beta$, and rhTNF- $\alpha$ on total protein synthesis in bovine primary cultured hepatocytes. Cultured hepatocytes were incubated in the presence of 10 $\mathrm{U} / \mathrm{ml} \mathrm{rhIL}-6,100 \mathrm{U} / \mathrm{m} l$ rhIL- $1 \beta$, and $100 \mathrm{U} / \mathrm{m} l$ rhTNF- $\alpha$. After incubation at $37^{\circ} \mathrm{C}$ for $24 \mathrm{hr}$, hepatocytes were labeled for $2 \mathrm{hr}$ with $300 \mathrm{kBq}\left[{ }^{35} \mathrm{~S}\right]$-methionine, and the incorporation of ${ }^{35} \mathrm{~S}$ into TCA-insoluble fractions in the medium was measured. Values are the means $\pm S E$ of four different experiments; i.e., four hepatocyte preparations from three calves and one cow.

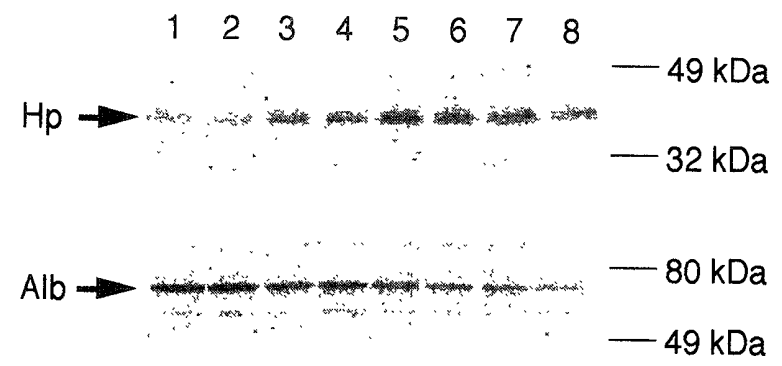

Fig. 2. Fluorograms of $\mathrm{Hp}$ and albumin synthesized by bovine primary cultured hepatocytes. Various concentrations of rhIL-6, 0 (lanes 1 and 2), 1 (lanes 3 and 4), 10 (lanes 5 and 6), and 100 (lanes 7 and 8) $\mathrm{U} / \mathrm{m} l$, were added to bovine primary cultured hepatocytes for $24 \mathrm{hr}$, and treated as Fig. 1. $\mathrm{Hp}$ and albumin were immunoprecipitated from the medium, subjected to SDS-PAGE and analyzed with BioImaging Analyzer BAS1000 as described in "MATERIALS AND METHODS".

shows effects of rhIL-6, rhIL- $1 \beta$, and rhTNF- $\alpha$ on total protein synthesis; i.e., ${ }^{35}$ S-incorporation into TCAinsoluble fractions in the culture medium. Neither cytokine showed any significant stimulatory effect on total protein synthesis. To estimate Hp and albumin synthesis, these two proteins in the culture medium were immunoprecipitated and electrophoretically separated. Figure 2 shows a typical example of electrophoretograms. For Hp, as expected, SDS-PAGE gave a band of $35 \mathrm{kDa}$ corresponding to $\beta$ chain of bovine $\mathrm{Hp}$. Alpha chain $(20 \mathrm{kDa})$ was not detected because it did not contain methionine. For albumin, a band of $67 \mathrm{kDa}$ was detected. It seems obvious that Hp synthesis was increased with increasing
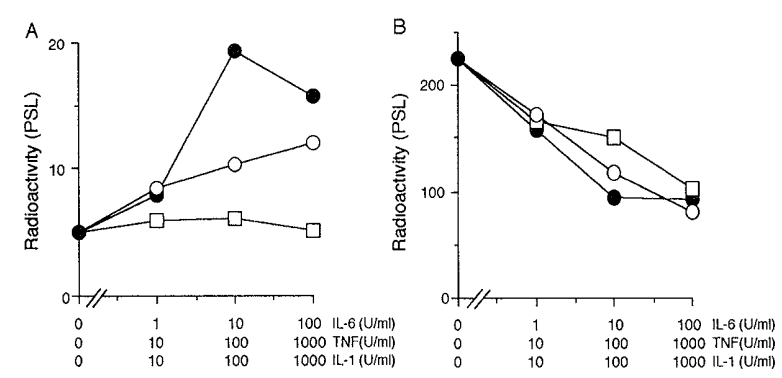

Fig. 3. Dose-response of $\mathrm{Hp} \mathrm{(A)} \mathrm{and} \mathrm{albumin} \mathrm{(B)} \mathrm{synthesis}$ to increasing concentrations of rhIL- 6 , rhIL- $1 \beta$, and rhTNF$\alpha$ in bovine primary cultured hepatocytes. Hepatocytes were incubated at various concentrations of rhIL-6(-), rhTNF$\alpha(\bigcirc)$, and rhIL-1 $\beta(\square)$, and treated as in Fig. 2. Values are means for four different experiments. SE was less than $30 \%$ of the respective means.

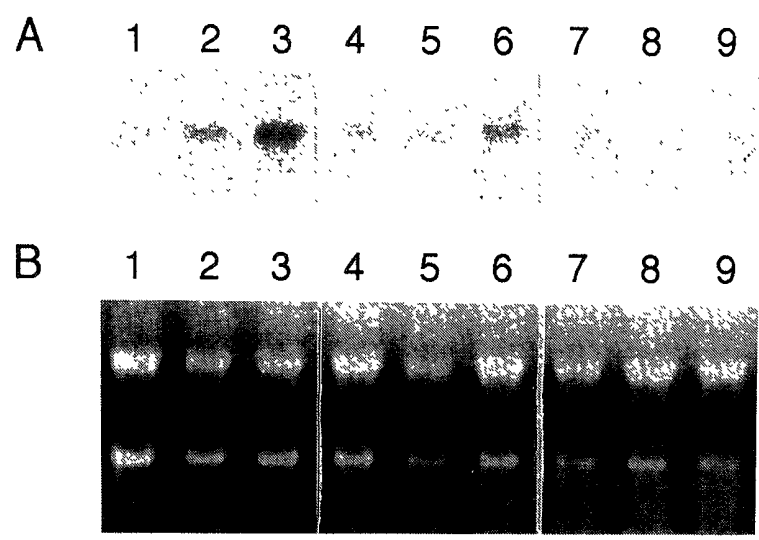

Fig. 4. Northern blot analysis of $\mathrm{Hp}$ mRNA in bovine primary cultured hepatocytes. Bovine primary cultured hepatocytes were incubated in the presence of 0 (lane 1$), 1$ (lane 2), 10 (lane 3) U/m $l$ rhIL-6, 0 (lane 4), 10 (lane 5), 100 (lane 6) $\mathrm{U} / \mathrm{m} l \mathrm{rhTNF}-\alpha$, and 0 (lane 7), 10 (lane 8), 100 (lane 9) $\mathrm{U} / \mathrm{m} l \mathrm{rhIL}-1 \beta$. After $24 \mathrm{hr}$ incubation, total RNA (10 $\mu \mathrm{g} /$ lane) was isolated from the cells, separated by electrophoresis in $1.5 \%$ agarose/formaldehyde gel, transferred to nylon membrane, and hybridized with a ${ }^{32} \mathrm{P}$-labeled cDNA probe for $\mathrm{Hp}(\mathrm{A}) . \mathrm{B}$ is ethidium bromide stain of the gel for A.

concentrations of rhIL-6, whereas albumin decreased. To analyze the results quantitatively, the radioactivity of each band was determined with a Bio-Imaging Analyzer. ANOVA revealed that rhIL-6 increased Hp synthesis $(\mathrm{P}<0.01)$ and decreased albumin synthesis $(\mathrm{P}<0.01)$ in dose-dependent manners (Fig. 3). rhTNF- $\alpha$ also stimulated $\mathrm{Hp}$ synthesis $(\mathrm{P}<0.01)$, although the maximal level at $1,000 \mathrm{U} / \mathrm{m} l$ was about two thirds of that by $10 \mathrm{U} / \mathrm{m} l$ rhIL-6 (Fig. 3A). In contrast, rhIL-1 $\beta$ showed no significant effect even at a dose of $1,000 \mathrm{U} / \mathrm{m} l$. On the other hand, rhIL- $1 \beta$ was as effective as rhIL- 6 and rhTNF- $\alpha$ in suppressing albumin synthesis (Fig. 3B).

To determine whether the effects of cytokines are at the step of transcription, we measured mRNA level of Hp by 
Northern blot analysis after stimulation of hepatocytes with the cytokines for $24 \mathrm{hr}$. As shown in Fig. 4, Hp mRNA level was increased by rhIL- 6 and $\operatorname{rhTNF}-\alpha$, but not by rhIL-1 $\beta$.

\section{DISCUSSION}

In this study, we demonstrated that, in bovine primary cultured hepatocytes, Hp synthesis was increased by rhIL- 6 and rhTNF- $\alpha$, but not by rhIL- $\beta$. These effects are specific to $\mathrm{Hp}$ synthesis, since total protein synthesis was not changed by these cytokines. The stimulatory effects of cytokines were mainly pretranslational, because mRNA level of $\mathrm{Hp}$ changed in parallel with protein synthesis. These results are consistent with recent studies demonstrating that almost all APPs are transcriptionally regulated by cytokines through the activation of transcription factors such as NF-IL6, acute-phase response factor (APRF), and NFxB [6, 14, 17, 24, 27].

It has been proposed that APPs can be classified into two major types: type 1 APP is regulated by IL- 1 and TNF, whereas type 2 APP by IL-6 [4, 6]. For example, rat $\mathrm{Hp}$ is a type $1 \mathrm{APP}$ while human Hp type $2[3,6,7]$. This classification is based on the difference in the responses to these cytokines of rodent and human APPs. In fact, it is known that IL-1 and TNF shared considerable overlap in their signal transduction mechanism of APP genes expression $[2,5,6,21]$. In the present study, however, we demonstrated that bovine $\mathrm{Hp}$ belonged to neither type: that is, $\mathrm{Hp}$ synthesis in bovine hepatocyte primary cultures was increased by rhIL- 6 and rhTNF- $\alpha$, but not by rhIL- $1 \beta$. It is possible that rhIL- $1 \beta$ is incapable of acting on bovine hepatocytes because of species specificity. However, the IL-1-specific signal pathways of our bovine hepatocytes were obviously activated during incubation with $\operatorname{rhIL}-1 \beta$, because albumin synthesis was effectively suppressed by this cytokine. Thus, unlike in rodent or human hepatocytes, TNF and IL-1 certainly do not overlap in their signal transduction in bovine hepatocytes, at least in Hp gene expression. A similar dissociation between the responses to IL-1 and TNF was also suggested in complement component 3 and $\alpha_{1}$-acid glycoprotein expression in a rat hepatoma cell line [5]. Taken together, the classification of type 1 APP requires further careful examinations. Although the synthesis of bovine Hp was strongly stimulated by rhIL- 6 as shown in this study, it is not an ordinal type 2 APP. TNF and IL- 1 do not stimulate any type 2 APP gene in other species [10]. On the contrary, rhTNF- $\alpha$, effectively stimulated the synthesis of bovine $\mathrm{Hp}$. All these results collectively suggest that there is a species specific unique signaling system in TNFinduced transcriptional activation of bovine $\mathrm{Hp}$ gene.

In bovine, serum $\mathrm{Hp}$ level increases more than 100-fold by inflammatory stimuli or injection of rhIL-6 [15, 19, 26]. A maximal level appears in $24 \mathrm{hr}$ after injection of turpentine oil, a typical inducer of inflammation [15]. A single injection of high doses of rhIL-6 induces a smaller response, whereas continuous infusion of low doses of
rhIL-6 produces a great response comparable to that after turpentine oil injection [19]. In consistent with these previous in vivo findings, the present study confirmed that rhIL-6 actually stimulated Hp synthesis in in vitro primary cultured bovine hepatocytes. However, the extent of increase in Hp synthesis by rhIL-6 in vitro was only several fold, being much less than that by in vivo inflammatory stimuli. These findings suggest that rhIL-6 alone is not enough to induce maximal $\mathrm{Hp}$ response and that the IL-6 action is mediated in part by some other factor(s). Although we found unexpectedly the unique stimulatory effect of rhTNF- $\alpha$ on in vitro Hp synthesis, the elevation was still small by rhTNF- $\alpha$ alone and even in combination with rhIL-6. Recent reports indicate that some growth factors such as transforming growth factor- $\beta$ and hepatocyte growth factor modulate hepatic APP synthesis [5, 25], leading a suggestion that these and other unknown factors may influence $\mathrm{Hp}$ synthesis in bovine liver. Alternatively, it is also possible that the difference of the activity of in vivo and in vitro hepatocytes may be due to some changes of properties of the cultured cells. In fact, while $\mathrm{Hp}$ is undetectable in sera of normal healthy cows, considerable amount of $\mathrm{Hp}$ was secreted even in unstimulated control hepatocyte cultures. These problems make it difficult to compare directly in vivo and in vitro data. Further studies are required to identify factors contributing to in vivo $\mathrm{Hp}$ responses.

ACKNOWLEDGEMENTS. We are grateful to Dr. K. Ochiai (Faculty of Veterinary Medicine, Hokkaido University) and Dr. K. Yamashita (School of Veterinary Medicine, Rakuno Gakuen University) for generously providing us with calves, and Dr. C. Sugimoto (Faculty of Veterinary Medicine, Hokkaido University) for generously offering us with a cowshed. This work was supported in part by Grant-in-Aid (No. 05760216 and No. 06760249) from the Ministry of Education, Science and Culture, Japan, and grants from the Akiyama Foundation and from the Kuribayashi Foundation.

\section{REFERENCES}

1. Andus, T., Geiger, T., Hirano, T., Kishimoto, T., TranThi, T.-A., Decker, K., and Heinrich, P. C. 1988. Regulation of synthesis and secretion of major rat acute-phase proteins by recombinant human interleukin-6 (BSF-2/IL-6) in hepatocyte primary cultures. Eur. J. Biochem. 173: 287-293.

2. Andus, T., Geiger, T., Hirano, T., Kishimoto, T., and Heinrich, P. C. 1988. Action of recombinant human interleukin 6 , interleukin $1 \beta$ and tumor necrosis factor $\alpha$ on the mRNA induction of acute-phase proteins. Eur. J. Immunol. 18: 739-746.

3. Baumann, H., Onorato, V., Gauldie, J., and Jahreis, G. P. 1987. Distinct sets of acute phase plasma proteins are stimulated by separate human hepatocyte-stimulating factors and monokines in rat hepatoma cells. J. Biol. Chem. 262: 9756-9768.

4. Baumann, H., Prowse, K. R., Marinković, S., Won, K-A., and Jahreis, G. P. 1989. Stimulation of hepatic acute phase response by cytokines and glucocorticoids. Ann. New York Acad. Sci. 557: 280-296. 
5. Baumann, H., Morella, K. K., and Wong, G. H. W. 1993. TNF- $\alpha$, IL- $1 \beta$, and hepatocyte growth factor cooperate in stimulating specific acute phase plasma protein genes in rat hepatoma cells. J. Immunol. 151: 4248-4257.

6. Baumann, H. and Gauldie, J. 1994. The acute phase response. Immunol. Today 15: 74-80.

7. Castell, J. V., Gómez-Lechón, M. J., David, M., Andus, T., Geiger, T., Trullenqus, R., Fabra, R., and Heinrich, P. C. 1989. Interleukin-6 is the major regulator of acute phase protein synthesis in adult human hepatocytes. FEBS Lett. 242: $237-239$.

8. Chomczynski, P. and Sacchi, N. 1987. Single-step method of RNA isolation by acid guanidinium thiocyanate-phenolchloroform extraction. Anal. Biochem. 162: 156-159.

9. Elsdale, T. and Bard, J. 1972. Collagen substrata for studies on cell behavior. J. Cell Biol. 54: 626-637.

10. Gauldie, J., Richards, C., Harnish, D., Lansdorp, P., and Baumann, H. 1987. Interferon $\beta_{2}$ /B-cell stimulatory factor type 2 shares identity with monocyte-derived hepatocytesstimulating factor and regulates the major acute phase protein response in liver cells. Proc. Natl. Acad Sci. U.S.A. 84: 7251-7255.

11. Heinrich, P. C., Castell, J. V., and Andus, T. 1990. Interleukin- 6 and the acute phase response. Biochem. $J$. 265: 621-636.

12. Higuchi, H., Katoh, N., Miyamoto, T., Uchida, E., Yuasa, A., and Takahashi, K. 1994. Dexamethasone-induced haptoglobin release by calf liver parenchymal cells. Am.J. Vet. Res. 55: 1080-1085.

13. Laemmli, U. K. 1970. Cleavage of structural proteins during the assembly of the head of bacteriophage T4. Nature (Lond.) 227: 680-685.

14. Lowell, C. A., Stearman, R. S., and Morrow, J. F. 1986. Transcriptional regulation of serum amyloid A gene expression. J. Biol. Chem. 261: 8453-8461.

15. Morimatsu, M., Tosa, N., Naiki, M., and Saito, M. 1992. Acute phase response of haptoglobin in cattle assessed by a single radial immunodiffusion method. Proc. Jpn. Soc. Anim. Biochem. 29: 61-68.

16. Morimatsu, M., Sarikaputi, M., Syuto, B., Saito, M., Yamamoto, S., and Naiki, M. 1992. Bovine haptoglobin: single radial immunodiffusion assay of its polymeric forms and dramatic rise in acute-phase sera. Vet. Immunol. Immunopathol. 33: 365-372.

17. Morrone, G., Ciliberto, G., Oliviero, S., Arcone, R., Dente, L., Content, J., and Cortese, R. 1988. Recombinant interleukin 6 regulates the transcriptional activation of a set of human acute phase genes. J. Biol. Chem. 263: 12554-12558.

18. Nakagawa-Tosa, N., Morimatsu, M., Mominoki, K., Nakatsuji, H., Syuto, B., and Saito, M. 1994. Isolation and primary culture of bovine hepatocytes: albumin synthesis and adrenergic activation of glycogenolysis. J. Vet. Med. Sci. 56: $125-129$.

19. Nakajima, Y., Momotani, E., Murakami, T., Ishikawa, Y., Morimatsu, M., Saito, M., Suzuki, H., and Yasukawa, K. 1993. Induction of acute phase protein by recombinant human interleukin-6 (IL-6) in calves. Vet. Immunol. Immunopathol. 35: 385-391.

20. Puissant, C. and Houdebine, L.-M. 1990. An improvement of the single-step method of RNA isolation by acid guanidinium thiocyanate-phenol-chloroform extraction. BioTechniques 8: 148-189.

21. Ramadori, G., Damme, J. V., Rieder, H., and Meyer zum Büschenfelde, K.-H. 1988. Interleukin-6, the third mediator of acute-phase reaction, modulates hepatic protein synthesis in human and mouse. Comparison with interleukin $1 \beta$ and tumor necrosis factor- $\alpha$. Eur. J. Immunol. 18: 1259-1264.

22. Sambrook, J., Fritsch, E. F., and Maniatis, T. 1989. Analysis of RNA. pp. 7.37-7.52. In: Molecular Cloning. A Laboratory Manual, 2nd ed. (Sambrook, J., Fritsch, E. F., and Maniatis, T. eds.), Cold Spring Harbor Laboratory Press, Cold Spring Harbor, NY.

23. Seed, B. and Aruffo, A. 1987. Molecular cloning of the $\mathrm{CD} 2$ antigen, the T-cell erythrocyte receptor, by a rapid immunoselection procedure. Proc. Natl. Acad. Sci. U.S.A. 84: 3365-3369.

24. Steel, D. M. and Whitehead, A. S. 1994. The major acute phase reactants: C-reactive protein, serum amyloid $\mathrm{P}$ component and serum amyloid A protein. Immunol. Today 15: $81-88$.

25. Taylor, A. W., Ku, N.-O., and Mortensen, R. F. 1990. Regulation of cytokine-induced human C-reactive protein production by transforming growth factor- $\beta$. J. Immunol. 145: 2507-2513.

26. Travis, J. C., Garza, J., and Sanders, B. G. 1975. Structural characterization of polymeric haptoglobin from goats. Comp. Biochem. Physiol. 51B: 93-97.

27. Wegenka, U. M., Buschmann, J., Lütticken, C., Heinrich, P. C., and Horn, F. 1993. Acute-phase response factor, a nuclear factor binding to acute-phase response elements, is rapidly activated by interleukin- 6 at the posttranslational level. Mol. Cell. Biol. 13: 276-288. 